\title{
Kepemimpinan Kewirausahaan Pondok Pesantren dari Sisi Perempuan
}

\author{
Romadhon1, Nyayu Khodijah'2, Mgs. Nazaruddin ${ }^{3}$ \\ ${ }^{1}$ Pondok Pesantren Modern Darussalam Prabumulih, Sumatera Selatan, Indonesia \\ 2,3Universitas Islam Negeri Raden Fatah Palembang, Sumatera Selatan, Indonesia \\ ajihsindon@gmail.com ${ }^{1}$
}

\begin{abstract}
This article discusses women's leadership in increasing entrepreneurship in Darussalam Prabumulih Modern Islamic Boarding School. The purpose of this study was to see the leadership characteristics developed at the Modern Darussalam Prabumulih Islamic Boarding School in increasing entrepreneurship. This research method uses a qualitative method with a descriptive approach. Selection of informants by purposive sampling technique and snowball sampling technique. Data collection techniques using observation, interviews, documentation, and triangulation. The results show that the criteria for women's leadership through entrepreneurship are demonstrated through the ability to anticipate change, develop a vision, and strategy. Ability to anticipate changes made, among others, examine any changes that occur, develop alternatives, carry out evaluations and carry out monitoring actions. The ability to develop a vision includes focusing on organizational goals, developing a vision for the future of the organization, and always being aware of changing customer needs. Meanwhile, the ability to have a strategy in the form of formulation or planning, implementation or action, and evaluation stage. To increase entrepreneurial activities, it is necessary to carry out continuous activities by entrepreneurial leaders and administrators. Teamwork and communication are the main keys to implementing an entrepreneurial activity program.
\end{abstract}

Keywords: leadership, entrepreneurship, and improvement efforts

\begin{abstract}
Abstrak. Artikel ini membahas tentang kepemimpinan perempuan dalam meningkatkan kewirausahaan di Pondok Pesantren Modern Darussalam Prabumulih. Tujuan penelitian ini untuk melihat karakteristik kepemimpinan yang dikembangkan di Pondok Pesantren Modern Darussalam Prabumulih dalam meningkatkan kewirausahaan. Metode penelitian ini menggunakan metode kualitatif dengan pendekatan deskriptif. Pemilihan infoman dengan teknik purposive sampling dan teknik snowball sampling. Teknik pengumpulan data menggunakan observasi, wawancara, dokumentasi, dan triangulasi. Hasil penelitian menunjukan bahwa kriteria kepemimpinan perempuan melalui kewirausahaan ditunjukkan melalui kemampuan mengantisipasi perubahan, mengembangkan visi, dan strategi. Kemampuan mengantisipasi perubahan yang dilakukan antara lain meneliti setiap perubahan yang terjadi, mengembangkan alternatif, melaksanakan evaluasi dan melaksanakan tindakan Monitoring. Kemampuan mengembangkan visi yang dilakukan antara lain fokus pada tujuan organisasi, mengembangkan visi bagi masa depan organisasi, dan selalu mengetahui perubahan kebutuhan pelanggan. Sedangkan, kemampuan memiliki strategi berupa formulasi atau perencanaan, implementasi atau tindakan, dan tahap evaluasi. Untuk meningkatkan kegiatan kewirausahaan perlu dilakukan secara berkesinambungan oleh pimpinan maupun pengurus kewirausahaan. Kerjasama tim dan komunikasi menjadi kunci utama terlaksananya program kegiatan kewirausahaan.
\end{abstract}

Kata Kunci: kepemimpinan, entrepreneurship, dan usaha peningkatannya

\section{PENDAHULUAN}

Kehadiran pondok pesantren di tengah-tengah masyarakat pada awalnya tidak hanya sebagai lembaga pendidikan saja, tetapi juga sebagai lembaga 
penyiar agama Islam. Pondok pesantren memang memiliki banyak keunikan dan kelebihan dibanding dengan lembaga pendidikan formal lainya. Pondok pesantren merupakan satu-satunya lembaga pendidikan yang tafaqqhu fiddien, memahami manusia dalam urusan agama (Ayu, 2019). Pendidikan agam dilakukan dalam segala aspek kehidupan, sehingga para kyai tidak hanya mencerdaskan para santrinya tetapi juga mendidik moral dan spiritual (Bashori, 2017: 13).

Kehadiran perempuan sebagai pemimpin publik telah banyak dibuktikan oleh sejarah, suksesi perempuan tersebut adalah bukti kualitas diri yang ada pada perempuan tersebut (Krisdiyanto, 2019: 18). Disinilah kita melihat bahwa ada lembaga yang berkualitas dalam memasok sumberdaya perempuan yang berkualitas yakni dengan didirikanya organisasi-organisasi perempuan. Mereka berperan menjadi salah satu kekuatan yang menggerakan perubahan social (Sudarsih, 2018).

Pondok pesantren Modern Darussalam Kota Prabumulih adalah salah satu lembaga pendidikan yang dipimpin oleh seorang perempuan. Secara teoritis, kebanyakan pesantren dipimpin oleh seorang Kyai (laki-laki) (Syafe'I, 2017), maka hal ini membuat sesuatu yang berbeda dari pondok pesantren lainya. Hal inilah yang menjadikan Pondok Pesantren Modern Darussalam menjadi unik.

Dengan pimpinan seorang perempuan mampu membawa perubahan bagi pengembangan pondoknya. Pondok Pesantren Modern Darussalam Kota Prabumulih sampai saat ini masih berkembang dan mampu bersaing ditengahtengah arus globalisasi yang tidak terbendung. Ini membuktikan bahwa beliau memiliki peran yang sangat penting dalam menjalankan roda kepemimpinanya di Pondok Pesantren Modern Darussalam Kota Prabumulih. Hal ini dikarenakan berkembang atau tidaknya suatu lembaga pendidikan ditentukan oleh faktor dominan oleh pimpinannya. Hal ini sesuai dengan pendapat Amran (2015) bahwa faktor dominan perkembangan lembaga dapat ditentukan oleh kepemimpinan, pendidik dan tenaga kependidikan, kurikulum, konteks/lingkungan, peserta didik dan proses pembelajaran. Tipe kepemimpinan inilah yang membuat pesantren mengalami perkembangan yang cukup signifikan.

Untuk meningkatkan kemandirian Pondok Pesantren dapat salah satunya melalui pemimpin yang memiliki jiwa wirausaha. Pemimpin yang memiliki jiwa wirausaha yaitu seorang pemimpin yang mempunyai kemampuan untuk mengantisipasi berbagai perubahan dengan visi masa depan yang jelas, serta berupaya mendorong suatu kerjasama dalam melakukan perubahan melalui fleksibelitas dalam menjalankan perannya 
$\overline{\text { mengelola organisasi (Abdulloh, 2014). Menurut Kurtako dan Hodgetts ada } 6}$ kriteria seorang pemimpin entrepreneur, yaitu: kemampuan mengantisipasi perubahan, mempunyai visi, berorientsi masa depan, berpikir strategis, fleksibel, menginisiasi perubahan (Saputra, 2016: 92).

Kepemimpinan seorang perempuan di Pondok Pesantren tersebut ditunjukkan dengan mengajarkan kewirausahaan kepada santri-santrinya. Adapun jenis kewirausahaan yang diajarkan diantaranya koperasi pesantren, menjahit, tata boga, pemeliharaan kebun sawit, dan kolam Bio Flok. Dengan berbagai macam wirausaha inilah, kemandirian Pondok Pesantren Modern Darussalam semakin hari semakin meningkat, dan ini juga menambah keunikan yang ada di Pondok Pesantren Modern Darussalam Kota Prabumulih.

Berdasarkan uraian diatas, penulis tertarik dan berkeiginan meneliti, mengkaji serta menganalis bagaimana peran seorang perempuan dalam memimpin Pondok Pesantren Modern Darussalam Kota Prabumulih, Sehubungan dengan hal itu, penulis akan meneliti dengan judul Kepemimpinan Kewirausahaan Pondok Pesantren dari Sisi Perempuan.

\section{KAJIAN LITERATUR}

Pemimpin artinya adalah kemampuan seseorang untuk mempengaruhi suatu kelompok kearah tercapainya tujuan yang sama. Kurtako dan Hodgetts menjelaskan bahwa kepemimpinan adalah "Leadership is the ability to influence, motivate, and enable other to contribute to the effectiveness and success of the organization of which they are member" (Priyatno, 2016). Kepemimpinan adalah kemampuan seseorang untuk mempengaruhi, memotivasi, dan memberlakukan aturan untuk berkontribusi pada keefektifan dan keberhasilan sebuah organisasi yang mana mereka adalah anggotanya. Dari definisi tersebut terlihat jelas beberapa hal penting terkait dengan makna kepemimpinan yaitu: interaksi 2 orang atau lebih dalam suatu kelompok, kemampuan mempengaruhi kelompok untuk mencapai tujuan, proses mempengaruhi bawahan, menggerakan orang untuk melakukan sesuatu, dan kemampuan mengerjakan sesuatu melalui dan dengan orang lain (Yohanis dan Agus, 2015: 89).

\section{Kewirausahaan}

Kewirausahaan secara istilah yaitu mengubah pola produksi dengan jalan memanfaatkan sebuah penemuan baru. Secara lebih umum sebuah kemungkinan teknologi untuk memproduksi sebuah komoditi baru atau memproduksi sebuah komoditi lama dengan cara baru, membuka sebuah 
sumber suplai bahan-bahan baru, suatu cara penyaluran baru, mengorganisasi sebuah industry baru (Zuanita, 2018). Pengertian ini mengandung maksud bahwa seorang wirausahawan adalan orang yang memiliki kemampuan untuk menciptakan sesuatu yang baru, berbeda dari yang lain, atau mampu menciptakan sesuatu yang berbeda dengan yang sudah ada sebelumnya. Sedangkan kata wirausaha berasal kata wira dan usaha. Wira artinya pahlawan, laki-laki, perwira. Usaha artinya perbuatan, prakarsa, ikhtiar, daya upaya atau kegiatan dengan mengerahkan tenaga, pikiran atau badan untuk mencapai suatu maksut (Helisia \& Eko, 2019). Jadi, wirausaha adalah orang yang menjalankan usaha atau peruasahaan dengan kemungkinan untung atau rugi.

Kepemimpinan kewirausahaan merupakan kepemimpinan dimana pemikiran, sikap, dan perilaku pemimpin menerapkan prinsip kewirausahaan serta berupaya mendorong suatu kerjasama dalam melakukan perubahan melalui fleksibilitas dalam menjalankan perannya mengelola organisasi (Wahyu, 2018). Pemimpin yang berwirausaha berusaha menggunakan pengaruhnya untuk menjadikan kegiatan organisasi mempunyai posisi yang berbeda melalui berbagai kebijakan yang dapat merubah organisasi meskipun hal yang dilakukan itu akan berbeda dengan yang lain, dan ini dilakukan dengan suatu keyakinan dan optimism (Arifin, 2019).

\section{Pondok Pesantren}

Pondok Pesantren secara istilah didefinisikan sebuah lembaga pendidikan Islam tertua yang berfungsi sebagai benteng pertahanan dan pusat dakwah serta pengembangan Islam Indonesia (Imam, S, 2017: 26). Pondok pesantren pada dasarnya sebuah pengajian yang dilakukan oleh seorang kiyai dalam satu tempat, berupa masjid, langgar atau musholla kecil. Sistem pembelajaran ada dua, pertama: dari segi materi pelajaran kitab kuning, tinggi rendahnya ilmu seseorang di ukur dari kitab yang dipelajarinya; kedua: dari segi metodenya yaitu berupa sorogan, bandongan dan wetonan, mengedepankan hafalan serta menggunakan sistem halaqoh (Ferdinand, 2016: 30).

\section{METODE PENELITIAN}

Metode penelitian yang digunakan yaitu berupa penelitian kualitatif. Metode kualitatif adalah metode penelitian yang berlandaskan pada filsafat postpositivisme, digunakan untuk meneliti pada kondisi obyek yang alamiah, (sebagai lawannya adalah eksperimen) di mana peneliti adalah sebagai instrumen kunci, pengambilan sampel sumber data dilakukan secara purposive dan snowball. Teknik pengumpulan dengan trianggulasi (gabungan), 
analisis data bersifat induktif/ kualitatif, dan hasil penelitian keualitatif lebih menekankan makna dari pada generalisasi (Sugiyono, 2016: 15).

Jenis penelitian yang digunakan peneliti yaitu penelitian lapangan (field research) denga fokus utama pada kepemimpinan kewirausahaan dan usaha peningkatanya. Pendekatan yang digunakan yaitu deskriptif, yaitu menggambarkan dan atau mendeskripsikan karakteristik dari fenomena, yang kemudian dipaparkan dalam bentuk naratif, yaitu memaparkan dalam bentuk uraian kata-kata kemudian menjadi sebuah kalimat dan paragraf yang sistematis (Ulfatin, 2015: 25). Sedangankan untuk pemilihan infoman dalam penelitian ini menggunakan teknik purposive sampling dan teknik snowball sampling. Informan dipilih berdasarkan atas subyek yang menguasai permasalahan, memiliki data dan bersedia memberikan informasi yang lengkap dan akurat. Teknik pengumpulan data menggunakan observasi, wawancara, dokumentasi, dan trianggulasi; analisis data menggunakan analisis Milles dan Huberman yaitu reduksi data, data display, dan verifikasi data.

\section{HASIL DAN PEMBAHASAN}

Kepemimpinan kewirausahaan telah banyak dipergunakan pada berbagai organisasi public. Kepemimpinan ini dilakukan untuk meningkatkan keefektifan sektor publik. Kepemimpinan kewirausahaan sebagai suatu model dalam memimpin sudah tentu dapat memberikan kontribusi produktif dalam mengelola dan memimpin organisasi apapun bidang kegiatan organisasi tersebut. Hal ini dikarenakan kepemimpinan kewirausahaan pada dasarnya adalah karakter, gaya atau tipe kepemimpinan yang dapat mendorong pada perubahan, Inovasi dan perkembangan organisasi lebih baik, efektif dan bermutu.

Terkait dengan kepemimpinan perempuan dalam meningkatkan kewirausahan di Pondok Pesantren Modern Darussalam Kota Prabumulih. Terdapat tiga karakteristik kepemimpinan kewirausahaan yaitu:

\section{Kemampuan Mengantisipasi Perubahan}

Sebagai seorang pemimpin di Pondok Pesantren Modern Darussalam Prabumulih, MS adalah salah satu perempuan yang menjadi pimpinan pondok pesantren yang berbeda dengan pondok pesantren lainnya, yang dimana pondok pesantren lain dipimpin oleh seorang Kyai (laki-laki) harus perlu mengetahui tentang dunia kewirausahaan dan berupaya agar menjadi budaya pondok pesantren yang dapat mewarnai masyarakat disekitarnya. Pentingnya memahami dunia kewirausahaan dimaksudkan agar pimpinan pondok 
pesantren memiliki kompetensi dan cara pandang dalam melakukan kepemimpinannya dengan tujuan dan maksud seperti apa nantinya.

Kemampuan mengantisipasi perubahan berupa perubahan yang bisa diprediksi dan ada yang tidak. Perubahan yang bisa diprediksi merupakan perubahan di masa datang yang kecenderungannya sudah tampak saat ini dan ini dipandang sebagai peluang. Sedangkan perubahan yang tidak bisa diprediksi merupakan ketidakpastian di mana perubahan lingkungan di masa datang tidak terlihat kecenderungannya saat ini. Pemahaman akan perubahan lingkungan pada dasarnya merupakan suatu tuntunan bagi setiap pemimpin, karena perubahan akan terus terjadi dengan tingkat dan gradasi yang mungkin berbeda-beda.

Adapun proses mengantisipasi perubahan atau ketika ada masalah yang terjadi maka serupa dengan proses perencanaan mencakup 3 tahapan yaitu meneliti setiap perubahan yang terjadi, mengembangkan alternatif-alternatif, melaksanakan alternatif terbaik dengan evaluasinya dan tindakan monitoring. Mencermati dari sistem kepemimpinan yang dilaksanakan oleh Pimpinan Pondok Pesantren Modern Darussalam Prabumulih berdasarkan hasil dokumentasi, wawancara, dan observasi selama penelitian berlangsung dapat disimpulkan bahwa kepemimpinan tersebut sudah dilakukan dengan baik, hal ini dapat dilihat dari langkah-langkahnya yang dapat dikemukaan sebagai berikut:

\section{a. Meneliti Setiap Perubahan yang Terjadi}

Jika terjadi perubahan yang tidak sesuai dengan seperti biasanya. Maka pimpinan akan merumuskan dan mengidentifikasi terlebih dahulu tentang perubahan yang ada, kemudian akan meyiapkan langkahlangkah alternatif untuk mengantispasi perubahan tersebut. Perubahan apapun yang terjadi tidak terpaku pada sosok pimpinan. Pimpinan selalu meminta pendapat sebelum merumuskan dan mengidentifikasi perubahan yang terjadi, terlebih dahulu memerlukan informasi yang mendalam tentang seluruh penyebab timbulnya perubahan tersebut.

\section{b. Mengembangkan Alternatif}

Masing-masing alternatif perlu dinilai sehubungan dengan tujuan-tujuan dan sumber daya organisasi yang bersangkutan. Selain itu alternatif perlu dinilai sehubungan dengan dampak yang akan ditimbulkan bagi organisasi yang bersangkutan. Alternatif yang dipilih oleh pimpinan Pondok Pesantren Modern Darussalam Kota Prabumulih sudah sesuai dengan kriteria tipikal yang dapat digunakan untuk mengevaluasi alternatif yaitu jangka waktu, asas biaya, dan manfaat.

\section{c. Memilih dan Melaksanakan Alternatif serta Tindakan Monitoring}


Pilihan Alternatif Pimpinan Pondok Pesantren Modern Darussalam Kota Prabumulih senantiasa melaksanakan tindakan monitoring atau pengawasan terhadap keputusan yang diambilnya. Kemudian, dilakukan evaluasi lebih lanjut dengan harapan keputusan alternatif yang diambil bisa berjalan dengan efektif.

\section{Kemampuan Mengembangkan Visi}

Pemimpin yang visioner mampu melihat tantangan dan peluang sebelum keduanya terjadi sambil kemudian memposisikan organisasi mencapai tujuan-tujuan terbaiknya. Selain itu, Seorang pemimpin visioner mampu mengantisipasi segala kejadian yang mungkin timbul, mengelola masa depan dan mendorong orang lain untuk berbuat dengan cara-cara yang tepat.

Kepemimpinan visioner yang dilaksanakan oleh Pimpinan Pondok Pesantren Modern Darussalam Prabumulih berdasarkan hasil dokumentasi, wawancara, dan observasi. Selama penelitian berlangsung dapat disimpulkan bahwa kepemimpinan tersebut sudah dilakukan dengan baik. Hal ini dapat dilihat dari langkah-langkahnya dalam mengembangkan visi, yaitu: fokus pada tujuan organisasi, mengembangkan visi bagi masa depan organisasi, selalu mengetahui perubahan kebutuhan pelanggan. Adapun penjelasannya sebagai berikut:

\section{a. Fokus pada Tujuan Organisasi}

Pimpinan Pondok Pesantren Modern Darussalam Prabumulih dalam melakukan pengembangan visi melalui langkah pertama yaitu fokus pada tujuan organisasi yaitu dengan penuh percaya diri dalam meraih tujuan organisasi bersama-sama dengan pengurus pondok pesantren yang lain.

\section{b. Mengembangkan Visi bagi Masa Depan Organisasi}

Pimpinan Pondok Pesantren Modern Darussalam Prabumulih dalam merumuskan visi sudah sesuai dengan kriteria yaitu dapat memberikan inspirasi dan motivasi bagi anggota dan aktivitas organisasi. Sedangkan dalam mengembangkan visi pondok pesantren, pimpinan senantiasa mensosialisasikan pada setiap kesempatan baik dilingkungan pondok pesantren maupun diluar publik secara umum. Selain itu, secara intern yaitu dengan menggugah dan memotivasi orang yang ada dibawahnya untuk bersama-sama menjalankan dan saling mendukung dalam berorganisasi (satu visi misi) serta berkomitmen terhadap visi tersebut.

\section{c. Mengetahui Perubahan Kebutuhan Pelanggan}

Untuk mengetahui perubahan kebutuhan pelanggan, pimpinan Pondok Pesantren Modern Darussalam Prabumulih melalui pengurus bidang 
kewirausahaan senantiasa menghubungi para pelanggannya untuk mengetahui kebutuhan yang diperlukan oleh pelanggan atau konsumen yang kemudian ditanggapi dan ditindak lanjuti oleh pondok pesantren tentang pengadaanya. Sehingga pelanggan tersebut merasakan pelayanannya dengan maksimal.

\section{Kemampuan Memiliki Strategi}

Strategi suatu organisasi bersifat dinamik, muncul dikit demi sedikit meyesuaikan dengan perkembang yang terjadi, senantiasa dievaluasi dan direvisi ketika pimpinan melihat adanya peluang untuk melakukan perbaikan. Kekurangan-kekurangan dan hambatan yang ada dijadikan bahan evaluasi untuk perbaikan progam kegiatan di Pondok Pesantren Modern Darussalam Prabumulih. Sehingga strategi yang dipilih bisa dijalankan dengan efektif dan efisien.

Sebuah strategi merupakan pola atau rencana yang menyatukan tujuan pokok suatu organisasi (Mukhlisah, 2014). Tujuan menyatakan apa saja yang perlu dicapai dan kapan hasil harus dilaksanakan. Mencermati dari sistem kepemimpinan yang dilaksanakan oleh Pimpinan Pondok Pesantren Modern Darussalam Prabumulih berdasarkan hasil dokumentasi, wawancara, dan observasi selama penelitian berlangsung dapat disimpulkan bahwa kepemimpinan tersebut sudah dilakukan dengan baik. hal ini dapat dilihat dari beberapa tahapan diantaranya Formulasi atau perencanaan, Implementasi atau tindakan, dan evaluasi. Untuk dapat lebih jelasnya dapat dikemukakan sebagai berikut:

\section{a. Tahap Formulasi}

Pimpinan sudah menentukan misi dan tujuan lembaga pendidikan yang didalamnya sudah mencakup pilihan-pilihan strategis yang akan dilakukan pondok pesantren ini baik jangka pendek, menengah dan panjang. Dengan mengamati lingkungan sekitar, melihat peluang dan tantangan serta menentukan kekuatan dan kelemahan internal pondok pesantren ini. Selain itu, terkait dengan kegiatan kewirausahaan, maka tahap formulasi (perencanaan) yang dilakukan pimpinan adalah dengan memperkenalkan dunia wirausaha kepada santri-santrinya melalui suatu kegiatan yang bernama Market Day.

\section{b. Tahap Implementasi}

Dalam tahap ini pimpinan sudah menetapkan tujuan atau sasaran tahunan. Kemudian diadakan rapat untuk membuat kebijakan-kebijakan baru dengan mengalokasikan sumber daya agar strategi yang telah 
(Kepemimpinan Kewirausahaan Pondok Pesantren dari Sisi Perempuan)

disusun bisa dijalankan. Selain itu juga, budaya yang mendukung pengembangan organisasi juga dibahas dalam rapat pengurus ini.

Selain itu, dalam tahap mengimplementasikan strategi ini terkait dengan kewirausahaan Pimpinan Pondok Pesantren Modern Darussalam Prabumulih yaitu dengan memberikan motivasi kepada santri-santrinya untuk mengikuti kegiatan kewirausahaan baik didalam maupun diluar pondok pesantren seperti seminar, pelatiahan, dan sebagainya. Selain itu, manfaat lainnya yaitu dapat mengembangkan produk yang sudah ada maupun yang belum ada.

\section{c. Tahap Evaluasi}

Pimpinan Pondok Pesantren Modern Darussalam Prabumulih telah melaksanakan tahapan akhir, yaitu tahap evaluasi karena tahapan strategi ini sangat dibutuhkan bagi pondok pesantren untuk suatu kesuksesan usaha yang akan diraih dimasa yang akan dating. Seringkali kesuksesan usaha pada masa sekarang bisa memunculkan persoalan yang baru dan berbeda jika tidak ada evaluasi.

Selain dari wawancara peneliti mendapat informasi dari Dokumen Pondok Pesantren Modern Darussalam Prabumulih yang tertulis pada buku Notulen Rapat pondok pesantren. Dari dokumen ini peneliti mendapat informasi bahwa sebulan sekali pondok pesantren ini melakukan rapat evaluasi yang bersifat seluruh bidang. Adapun rapat khusus bidang kewirausahaan diadakan dalam 1 semester (enam bulan) sekali dan waktu yang tidak ditentukan (ketika ada perubahan yang signifikan) terkait dengan kemampuan memiliki strategi kepemimpinan kewirausahaan di Pondok Pesantren Modern Darussalam Prabumulih maka tahap akhir ini sudah dilaksanakan dengan baik.

Pondok Pesantren yang tersebar diseluruh Indonesia sudah tidak asing lagi dengan kegiatan kewirausahaan. Dimana hampir setiap pondok pesantren sudah menerapkan kegiatan ini. Dalam meningkatkan usaha kewirausahaan di Pondok Pesantren Modern Darussalam, usaha yang dilakukan dengan menanamkan jiwa kewirausahaan kepada santri. Untuk meningkatkan jiwa kewirausahaannya memerlukan berbagai metode dan strategi yang berbedabeda di setiap pondok pesantren.

Berdasarkan hasil wawancara, dokumentasi, dan obsevasi selama penelitian berlangsung, dapat disimpulkan bahwa usaha yang dilakukan oleh pimpinan Pondok Pesantren Modern Darussalam Prabumulih dalam meningkatkan kegiatan kewirausahaan yaitu: 1) meningkatkan pengetahuan dan kesadaran kepada santri tentang kegiatan kewirausahaan dengan selalu 
memberikan aturan kedisiplinan, jadwal piket, motivasi, seminar, memberikan tugas dan tanggung jawab sesuai dengan kemampuannya; 2) meningkatkan fasilitas sarana dan prasrana wirausaha, dengan melakukan pemeliharaan, penambahan dan kerjasama dengan pihak pemerintah ataupun swasta; 3) kerjasama dengan perusahaan, pabrik, swasta atau pemerintah dan dinas pemerintah terkait; 4) memberikan penghargaan atau Reward kepada santri berprestasi bidang wirausaha pada acara-acara tertentu dan menudukung santri-santri dalam mengikuti lomba-lomba bidang wirausaha. Kepemimpinan perempuan dalam meningkatkan kewirausaha di Pondok Pesantren Modern Darussalam Prabumulih berdasarkan uraian data dan temuan peneliti diatas, secara garis besar telah terlaksana dengan baik dan efektif. Pimpinan maupun pengurus kewirausahaan selalu melakukan perbaikan-perbaikan terhadap apa yang menjadi kekurangan dan kendala kegiatan kewirausahaan. Selain itu juga, untuk meningkatkan kegiatan kewirausahaan ini terus dilakukan secara berkesinambungan oleh pimpinan maupun pengurus kewirausahaan. Kerjasama tim dan komunikasi menjadi kunci utama terlaksananya program kegiatan entrepreneurship, motivasi dan respon cepat dari pimpinan juga sangat baik sehingga setiap kekurangan dan kendala yang ada di program kewirausahaan ini selalu diperbaiki (Rahim, 2016).

\section{KESIMPULAN}

Kriteria kepemimpinan perempuan dalam meningkatakan kewirausahaan di Pondok Pesantren Modern Darussalam Prabumulih melalui kemampuan mengantisipasi perubahan (meneliti setiap perubahan yang terjadi, mengembangkan dan melaksanakan alternatif, dan melaksanakan tindakan monitoring), kemampuan mengembangkan visi (fokus pada tujuan organisasi, mengembangkan visi bagi masa depan organisasi, selalu mengetahui perubahan kebutuhan pelanggan), kemampuan memiliki strategi (formulasi atau perencanaan, Implementasi atau tindakan, dan evaluasi).

\section{DAFTAR PUSTAKA}

Abdulloh. (2014) Peran Kepemimpinan Nyai di Pondok Pesantren. Jurnal Saintekbu, 07(2),200-220.

Amran. (2015). Faktor Penentu Keberhasilan Pengelola Satuan Pendidikan. Manajer Pendidikan, 9 (2), 185-196.

Arifin, M. (2019) Peningkatan Kapasitas Santri Pondok Pesantren Entrepreneur. Jurnal Muria, 3(1), 22-27. 
$\overline{\text { Ayu, S. \& Rifa'I, M. (2019). Strategi Pimpinan dalam Pengelolaan Perubahan }}$ Organisasi. Jurnal Benchmarking: Manejemen Pendidikan Islam, 3(1), 39.

Bashori. (2017). Modernisasi Lembaga Pendidikan Pesantren. Sosial Review: Jurnal Ilmu Sosial Mamangan, 6 (1), 13.

Ferdinand, M. (2016) Pondok Pesantren dan Ciri Khas Perkembanganya. Tarbawi: Jurnal PendidikanAgama Islam, 01(1) 30

Krisdiyanto, G. (2019). Sistem Pendidikan Pesantren, Modernitas dan Tantangan. Jurnal Tarbawi: Jurnal Ilmu Pendidikan, 15 (1), 18

Helisia, M. \& Eko, T. (2019). Membangun Tradisi Entrepreneurship Pada Masyarakat. Jurnal Edunomika: Jurnal Ekonomi dan Bisnis, 3 (2), 30

Imam, S. (2017) Pondok Pesantren: Lembaga Pendidikan Pembentukan Karakter. Al-Tadzikyah: Jurnal Pendidikan Islam, 8(1), 26.

Mukhlisah. (2014). Persepsi tentang Kepemimpinan Perempuan. Jurnal Kependidikan Islam, 4 (1) 30-40.

Prayitno, P. (2016). Pemberdayaan sumber daya santri melalui Enterpreneurship di Pondok Pesantren. Jurnal Quality, 4 (2) 100-120.

Rahim, A. (2016). Peran Kepepmimpinan Perempuan dalam perspektif Gender. Jurnal Al-Maiyyah, 2 (2), 28-35

Saputra, U. (2016). Kepemimpinan Inovasi Pendidikan. Bandung: PT Refika Aditama

Sugiyono.(2016). Metode Penelitian Pendidikan Pendekatan Kuantitatif. Kualitatif. dan R\&D. Bandung: Alfabeta.

Sudarsih, E. (2018). Mengembangkan Wirausaha di Pondok Pesantren. Jurnal Sosial Humaniora, 7 (1) 10-20.

Syafe'I, I. (2017). Pondok Pesantren: Lembaga Pendidikan Pembentukan Karakter. Al-Tadzkiyyah: Jurnal Pendidikan Islam, 8, 85-103.

Ulfatin, N.(2015). Metodologi Penelitian Kualitatif di Bidang Pendidikan. Malang: MNC Publishing.

Wahyu, T. (2018). Kepemimpinan Bisnis Indonesia di Era Pasar Bebas. Jurnal Edunomika: Jurnal Ekonomi dan Pendidikan, 7 (1), 18.

Yohanis, S. \& Agus, S, S. (2015). Pengaruh Pemimpin terhadap Motivasi dan Kedisiplinan Kinerja Pegawai. Jurnal EMBA: Jurnal Ilmu Politik, 3 (5), 89.

Zuanita. (2018) Membangun Jiwa Enterpreneurship Santri Melalui Pengembangan Usaha Ekonomi Kreatif. Jurnal Dimas, 18(1), 90-100. 
$\longrightarrow$ 